\title{
Planomicrobium glaciei sp. nov., a psychrotolerant bacterium isolated from a glacier
}

\author{
De-Chao Zhang, ${ }^{1}$ Hong-Can Liu, ${ }^{1}$ Yu-Hua Xin, ${ }^{1}$ Yong $\mathrm{Yu}^{2}{ }^{2}$ Pei-Jin Zhou ${ }^{1}$ \\ and Yu-Guang Zhou ${ }^{1}$
}

Correspondence

Yu-Guang Zhou

zhouyg@sun.im.ac.cn

\author{
${ }^{1}$ China General Microbiological Culture Collection Center and State Key Laboratory of Microbial \\ Resources, Institute of Microbiology, Chinese Academy of Sciences, Beijing 100101, PR China \\ ${ }^{2}$ SOA Key Laboratory for Polar Science, Polar Research Institute of China, Shanghai 200136, \\ PR China
}

\begin{abstract}
A novel aerobic, psychrotolerant, yellow-to-orange bacterium (strain $0423^{\top}$ ) was isolated from the China No. 1 glacier. Strain $0423^{\top}$ displayed phenotypic and chemotaxonomic features of the genus Planomicrobium, containing anteiso- $\mathrm{C}_{15: 0}$ and iso- $\mathrm{C}_{14: 0}$ as the major fatty acids. The temperature range for growth was $4-28{ }^{\circ} \mathrm{C}$, with optimum growth at $20-21{ }^{\circ} \mathrm{C}$. The genomic DNA G + C content was 49 mol\%. Phylogenetic analysis based on 16S rRNA gene sequence similarity showed that strain $0423^{\top}$ was related to members of the genus Planomicrobium, sharing the highest sequence similarities with the type strains of Planomicrobium chinense, $P$.

mcmeekinii, $P$. okeanokoites and $P$. koreense. On the basis of phenotypic characteristics, phylogenetic analysis and DNA-DNA relatedness data, a novel species, Planomicrobium glaciei sp. nov., is proposed. The type strain is $0423^{\top}\left(=\right.$ CGMCC $\left.1.6846^{\top}=\mathrm{JCM} 15088^{\top}\right)$.
\end{abstract}

The genus Planomicrobium was proposed by Yoon et al. (2001). It currently accommodates aerobic, Gram-positive to Gram-variable, non-spore-forming and yellow-toorange-pigmented bacteria usually with a DNA $\mathrm{G}+\mathrm{C}$ content in the range $35-47 \mathrm{~mol} \%$. So far, the genus Planomicrobium comprises six species: Planomicrobium okeanokoites (Nakagawa et al., 1996; Yoon et al., 2001), P. momeekinii (Junge et al., 1998; Yoon et al., 2001), P. koreense (Yoon et al., 2001), P. alkanoclasticum (Engelhardt et al., 2001; Dai et al., 2005), P. psychrophilum (Reddy et al., 2002; Dai et al., 2005) and P. chinense (Dai et al., 2005).

The China No. 1 glacier, located in Xinjiang Uygur Autonomous Region, north-west China, is a relatively simple and closed ecosystem. Many cold-adapted microorganisms have been isolated from the area by members of our laboratory (Zhu et al., 2003; Zhang et al., 2006, 2007, 2008). In this study, we report the isolation and identification of strain $0423^{\mathrm{T}}$. Based on a polyphasic taxonomic approach, strain $0423^{\mathrm{T}}$ is identified as representing a novel species of the genus Planomicrobium.

Strain $0423^{\mathrm{T}}$ was isolated from frozen soil collected from the China No. 1 glacier using media and methods described elsewhere (Zhu et al., 2003). The strain was routinely

The GenBank/EMBL/DDBJ accession number for the $16 \mathrm{~S}$ rRNA gene sequence of strain $0423^{\top}$ is EU036220.

Cellular fatty acid compositions of strain $0423^{\top}$ and its phylogenetic relatives are available as supplementary material with the online version of this paper. grown aerobically at $20{ }^{\circ} \mathrm{C}$ on PYG medium (Zhang et al., 2006). P. chinense CGMCC $1.3454^{\mathrm{T}}$ and P. okeanokoites NBRC $12536^{\mathrm{T}}$ were respectively obtained from the CGMCC and the NBRC and P. momeekinii DSM $13963^{\mathrm{T}}$ and $P$. koreense DSM $15895^{\mathrm{T}}$ were obtained from the DSMZ. These cultures were grown routinely on marine 2216 agar (Difco) and used as reference strains.

DNA from strain $0423^{\mathrm{T}}$ was extracted and purified as described by Sambrook et al. (1989). The gene sequence encoding the $16 \mathrm{~S}$ rRNA was amplified by PCR with the forward primer $5^{\prime}$-AGAGTTTGATCCTGGCTCAG-3' and reverse primer 5' ${ }^{\prime}$-AAGGAGGTGATCCAGCCGCA-3' (Zhang et al., 2006). The PCR product was sequenced using an ABI BigDye 3.1 sequencing kit (Applied BioSystems) and an automated DNA sequencer (model ABI3730; Applied BioSystems). BLASTN searches with the nearly complete (1465 bp) 16S rRNA gene sequence of strain $0423^{\mathrm{T}}$ in GenBank and EMBL revealed that the novel isolate shared high sequence similarity $(\sim 98.0 \%)$ with members of the genus Planomicrobium. Phylogenetic trees were constructed using the neighbour-joining (Saitou \& Nei, 1987) and maximum-parsimony algorithms with Kimura's two-parameter calculation model (Kimura, 1980) implemented in the program MEGA version 3.0 (Kumar et al., 2004). The resultant tree topologies were evaluated by bootstrap analysis based on 1000 replicates. Phylogenetic analysis (Fig. 1) showed that strain $0423^{\mathrm{T}}$ grouped with members of the genus Planomicrobium, including $P$. chinense DX3-12 ${ }^{\mathrm{T}}(98.0 \%)$, P. momeekinii 


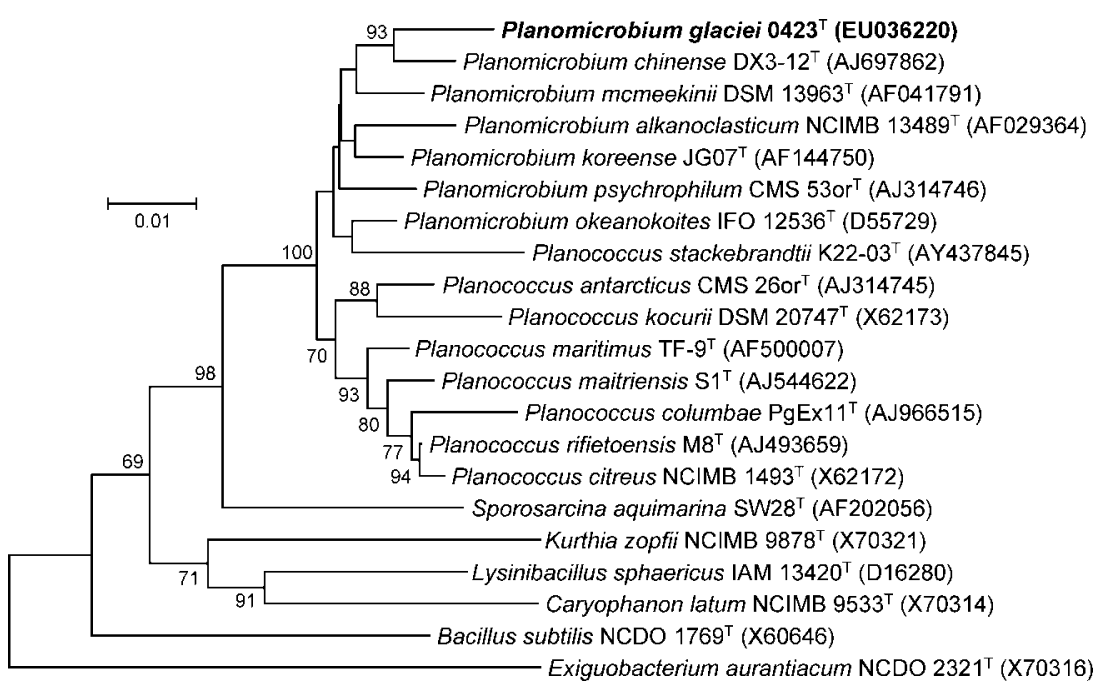

Fig. 1. Neighbour-joining tree based on $16 \mathrm{~S}$ rRNA gene sequences showing the phylogenetic relationships of strain $0423^{\top}$ and related species. The tree was rooted with Exiguobacterium aurantiacum NCDO $2321^{\top}$. Numbers at nodes represent bootstrap values higher than $50 \%$ (based on 1000 resampled datasets). Bar, $1 \%$ sequence divergence.
DSM $13963^{\mathrm{T}}(97.7 \%)$, P. okeanokoites IFO $12536^{\mathrm{T}}(97.5 \%)$ and $P$. koreense $\mathrm{JG} 7^{\mathrm{T}}(97.4 \%)$. Very similar tree topologies were obtained using the two different algorithms.

The cell morphology of strain $0423^{\mathrm{T}}$ was examined with an Axioplan 2 microscope (Zeiss). Colony morphology was observed on PYG agar after incubation at $20{ }^{\circ} \mathrm{C}$. The temperature range for growth was determined with a TN3F temperature-gradient incubator (Advantec). The $\mathrm{pH}$ range for growth was determined in PYG adjusted at various $\mathrm{pH}$ values with $1 \mathrm{M} \mathrm{HCl}$ or $\mathrm{NaOH}$.

General physiological tests were performed using conventional methods (Dong \& Cai, 2001). Acid production from carbohydrates was determined as described by Leifson (1963). In addition, biochemical traits were examined using the API 20 E, API $20 \mathrm{NE}$ and API ZYM kits (bioMérieux) according to the manufacturer's instructions. The morphological, cultural, physiological and biochemical characteristics of strain $0423^{\mathrm{T}}$ are given in the species description and in Table 1.

Respiratory quinones were extracted and purified according to Collins (1985) and were analysed by HPLC (Wu et al., 1989). Cells of strain $0423^{\mathrm{T}}$ contained menaquinone 7 (MK-7) and menaquinone 8 (MK-8) as the major respiratory quinones. Cell-wall peptidoglycan was prepared and analysed by the method described by Komagata \& Suzuki (1987) and Zhang et al. (2007). The cell-wall peptidoglycan of strain $0423^{\mathrm{T}}$ contained lysine, glutamic acid and alanine, but not ornithine; this is consistent with the A4 $\alpha$ type. For cellular fatty acid analysis, strain $0423^{\mathrm{T}}$ was grown in PYG at $20{ }^{\circ} \mathrm{C}$ for 3 days and $P$. chinense CGMCC $1.3454^{\mathrm{T}}$, P. momeekinii DSM $13963^{\mathrm{T}}$, P. okeanokoites NBRC $12536^{\mathrm{T}}$ and P. koreense DSM $15895^{\mathrm{T}}$ were grown in marine 2216 broth (Difco) at $28{ }^{\circ} \mathrm{C}$ for 3 days. Fatty acids were methylated and analysed using the standard Microbial Identification (MIDI) procedure (Sasser, 1990). The cellular fatty acids were anteiso- $\mathrm{C}_{15: 0}(36.97 \%)$, iso-
$\mathrm{C}_{14: 0} \quad(15.15 \%)$, iso- $\mathrm{C}_{16: 0} \quad(5.80 \%), \mathrm{C}_{16: 1} \omega 7 c$ alcohol $(4.55 \%), \mathrm{C}_{17: 0}(3.60 \%), \mathrm{C}_{16: 1} \omega 11 c(3.22 \%)$ and anteiso$\mathrm{C}_{17: 0}(3 \%)$. Detailed fatty acid profiles of strain $0423^{\mathrm{T}}$ and its phylogenetic relatives are shown in Supplementary Table S1, available in IJSEM Online.

The $\mathrm{G}+\mathrm{C}$ content of the DNA was tested by the thermal denaturation method (Sly et al., 1986) with Escherichia coli $\mathrm{K}-12$ as the reference strain. Levels of DNA-DNA hybridization were determined from the initial DNADNA liquid reassociation rate as described by De Ley et al.

Table 1. Differential phenotypic characteristics between strain $0423^{\top}$ and type strains of Planomicrobium species

Strains: 1, Planomicrobium glaciei sp. nov. $0423^{\mathrm{T}}$ (data from this study); 2, P. chinense DX3-12 ${ }^{\mathrm{T}}$ (Dai et al., 2005); 3, P. koreense JG07 ${ }^{\mathrm{T}}$ (Yoon et al., 2001); 4, P. mcmeekinii DSM $13963^{\mathrm{T}}$ (Junge et al., 1998); 5, P. okeanokoites NBRC $12536^{\mathrm{T}}$ (Nakagawa et al., 1996); 6, P. alkanoclasticum NCIMB $13489^{\mathrm{T}}$ (Engelhardt et al., 2001); 7, P. psychrophilum DSM $14507^{\mathrm{T}}$ (Reddy et al., 2002). +, Positive; -, negative; $(+)$ weakly positive; ND, no data available.

\begin{tabular}{|lccccccc|}
\hline Characteristic & $\mathbf{1}$ & $\mathbf{2}$ & $\mathbf{3}$ & $\mathbf{4}$ & $\mathbf{5}$ & $\mathbf{6}$ & $\mathbf{7}$ \\
\hline $\begin{array}{l}\text { Cell shape* } \\
\text { Growth at: }\end{array}$ & $\mathrm{C} / \mathrm{R}$ & $\mathrm{C} / \mathrm{R}$ & $\mathrm{C} / \mathrm{R}$ & $\mathrm{C} / \mathrm{R}$ & $\mathrm{R}$ & $\mathrm{R}$ & $\mathrm{R}$ \\
$\quad 4{ }^{\circ} \mathrm{C}$ & & & & & & & \\
$37{ }^{\circ} \mathrm{C}$ & + & - & + & + & - & - & + \\
NaCl tolerance (\%) & 11 & 10 & 7 & 7 & 7 & 6 & 12 \\
Nitrate reduction & + & + & - & + & - & - & - \\
Oxidase & - & - & - & - & $(+)$ & - & + \\
Degradation of: & & & & & & & \\
$\quad$ Casein & + & - & + & + & + & $\mathrm{ND}$ & $\mathrm{ND}$ \\
$\quad$ Starch & - & - & - & - & - & + & - \\
DNA G $+\mathrm{C}$ content & 49 & 34.8 & 47 & 35 & 46.3 & 45.3 & 44.5 \\
$\quad($ mol\%) & & & & & & & \\
\hline
\end{tabular}

${ }^{\star} \mathrm{C}$, Cocci; R, rods. 
(1970) and modified by Huß et al. (1983). The tests were performed on a model Lambda $35 \mathrm{UV} / \mathrm{Vis}$ spectrophotometer equipped with a temperature program controller (Perkin-Elmer). The DNA G +C content of strain $0423^{\mathrm{T}}$ was $49 \mathrm{~mol} \%$. The levels of DNA-DNA relatedness between strain $0423^{\mathrm{T}}$ and P. chinense CGMCC $1.3454^{\mathrm{T}}, P$. momeekinii DSM $13963^{\mathrm{T}}$, P. okeanokoites NBRC $12536^{\mathrm{T}}$ and $P$. koreense DSM $15895^{\mathrm{T}}$ were $45.7,36.8,35.3$ and $32.1 \%$, respectively.

Based on phenotypic, chemotaxonomic and molecular data, it is concluded that strain $0423^{\mathrm{T}}$ represents a novel species of the genus Planomicrobium, for which the name Planomicrobium glaciei sp. nov. is proposed.

\section{Description of Planomicrobium glaciei sp. nov.}

Planomicrobium glaciei (gla.ci'ei. L. gen. n. glaciei of ice, referring to the isolation source of the type strain, the China No. 1 glacier).

Cells are cocci in young cultures but change to short rods with age. Gram-positive, flagellated and gliding. Colonies are smooth, circular, convex with entire margins and yellow to orange in colour. Catalase-positive and oxidase-negative. Growth occurs at $4-28{ }^{\circ} \mathrm{C}$ and $\mathrm{pH}$ 5.0-10.0, with optimum growth at $20-21{ }^{\circ} \mathrm{C}$ and approximately $\mathrm{pH} 6.0-7.5$. Growth occurs in the presence of $0-11 \%(\mathrm{w} / \mathrm{v}) \mathrm{NaCl}$. Hydrolyses gelatin, casein and trypsin, but not starch or Tweens 20,60 or 80 . Reduces nitrate. Positive for alkaline phosphatase, naphthol-AS-BI-phosphohydrolase, $\beta$-galactosidase, $\alpha$-chymotrypsin, esterase lipase (C8), cystine arylamidase, leucine arylamidase and valine arylamidase. Negative for indole production, Voges-Proskauer test, arginine dihydrolase, lysine decarboxylase, ornithine decarboxylase, acid phosphatase, urease, $\alpha$-galactosidase, $\beta$-glucuronidase, $\beta$-glucosidase, $\alpha$-glucosidase and $\alpha$-fucosidase. The following substrates are utilized as sole carbon sources: cellobiose, trehalose, D-mannose, glucose, sucrose, L-arabinose, ribose, fructose and mannitol. The following substrates are not utilized as sole carbon sources: raffinose, xylose, Lrhamnose, melezitose and lactose. Acid is produced from ribose and glycerol. Cells contain MK-7 and MK- 8 as the major respiratory quinones. The peptidoglycan type is $\mathrm{A} 4 \alpha$ type. The cellular fatty acids are anteiso- $\mathrm{C}_{15: 0}$, iso- $\mathrm{C}_{14: 0}$, iso$\mathrm{C}_{16: 0}, \mathrm{C}_{16: 1} \omega 7 c$ alcohol, $\mathrm{C}_{17: 0}, \mathrm{C}_{16: 1} \omega 11 c$ and anteiso$\mathrm{C}_{17: 0}$. The $\mathrm{G}+\mathrm{C}$ content of the type strain is $49 \mathrm{~mol} \%$.

The type strain is $0423^{\mathrm{T}}$ (=CGMCC $1.6846^{\mathrm{T}}=\mathrm{JCM}$ $15088^{\mathrm{T}}$ ), isolated from the China No. 1 glacier (Xinjiang Uygur Autonomous Region, China).

\section{Acknowledgements}

This work was supported by the National Basic Research Program of China (2004CB719601).

\section{References}

Collins, M. D. (1985). Isoprenoid quinone analysis in classification and identification. In Chemical Methods in Bacterial Systematics, pp. 267-287. Edited by M. Goodfellow \& D. E. Minnikin. London: Academic Press.

Dai, X., Wang, Y.-N., Wang, B.-J., Liu, S.-J. \& Zhou, Y.-G. (2005). Planomicrobium chinense sp. nov., isolated from coastal sediment, and transfer of Planococcus psychrophilus and Planococcus alkanoclasticus to Planomicrobium as Planomicrobium psychrophilum comb. nov. and Planomicrobium alkanoclasticum comb. nov. Int J Syst Evol Microbiol 55, 699-702.

De Ley, J., Cattoir, H. \& Reynaerts, A. (1970). The quantitative measurement of DNA hybridization from renaturation rates. Eur $J$ Biochem 12, 133-142.

Dong, X.-Z. \& Cai, M.-Y. (editors) (2001). Determination of biochemical properties. In Manual for the Systematic Identification of General Bacteria, pp. 370-398. Beijing: Science Press (in Chinese).

Engelhardt, M. A., Daly, K., Swannell, R. P. J. \& Head, I. M. (2001). Isolation and characterization of a novel hydrocarbon-degrading, Gram-positive bacterium, isolated from intertidal sediment, and description of Planococcus alkanoclasticus sp. nov. J Appl Microbiol 90, 237-247.

Huß, V. A. R., Festl, H. \& Schleifer, K. H. (1983). Studies on the spectrophotometric determination of DNA hybridization from renaturation rates. Syst Appl Microbiol 4, 184-192.

Junge, K., Gosink, J. J., Hoppe, H.-G. \& Staley, J. T. (1998). Arthrobacter, Brachybacterium and Planococcus isolates identified from Antarctic sea ice brine. Description of Planococcus momeekinii, sp. nov. Syst Appl Microbiol 21, 306-314.

Kimura, M. (1980). A simple method for estimating evolutionary rates of base substitutions through comparative studies of nucleotide sequences. J Mol Evol 16, 111-120.

Komagata, K. \& Suzuki, K. (1987). Lipid and cell-wall analysis in bacterial systematics. Methods Microbiol 19, 161-207.

Kumar, S., Tamura, K. \& Nei, M. (2004). MEGA3: integrated software for molecular evolutionary genetics analysis and sequence alignment. Brief Bioinform 5, 150-163.

Leifson, E. (1963). Determination of carbohydrate metabolism of marine bacteria. J Bacteriol 85, 1183-1184.

Nakagawa, Y., Sakane, T. \& Yokota, A. (1996). Emendation of the genus Planococcus and transfer of Flavobacterium okeanokoites Zobell and Upham 1944 to the genus Planococcus as Planococcus okeanokoites comb. nov. Int J Syst Bacteriol 46, 866-870.

Reddy, G. S. N., Prakash, J. S. S., Vairamani, M., Prabhakar, S., Matsumoto, G. I. \& Shivaji, S. (2002). Planococcus antarcticus and Planococcus psychrophilus spp. nov. isolated from cyanobacterial mat samples collected from ponds in Antarctica. Extremophiles 6, 253-261.

Saitou, N. \& Nei, M. (1987). The neighbor-joining method: a new method for reconstructing phylogenetic trees. Mol Biol Evol 4, 406425.

Sambrook, J., Fritsch, E. F. \& Maniatis, T. (1989). Molecular Cloning: a Laboratory Manual, 2nd edn. Cold Spring Harbor, NY: Cold Spring Harbor Laboratory.

Sasser, M. (1990). Identification of bacteria by gas chromatography of cellular fatty acids, MIDI Technical Note 101. Newark, DE: MIDI Inc.

Sly, L. I., Blackall, L. L., Kraat, P. C., Tian-Shen, T. \& Sangkhobol, V. (1986). The use of second derivative plots for the determination of mol\% guanine plus cytosine of DNA by the thermal denaturation method. J Microbiol Methods 5, 139-156.

Wu, C., Lu, X., Qin, M., Wang, Y. \& Ruan, J. (1989). Analysis of menaquinone compound in microbial cells by HPLC. Microbiology [English translation of Microbiology (Beijing)] 16, 176-178.

Yoon, J.-H., Kang, S.-S., Lee, K.-C., Lee, E. S., Kho, Y. H., Kang, K. E. \& Park, Y.-H. (2001). Planomicrobium koreense gen. nov., sp. nov., a 
bacterium isolated from the Korean traditional fermented seafood jeotgal, and transfer of Planococcus okeanokoites (Nakagawa et al. 1996) and Planococcus momeekinii (Junge et al. 1998) to the genus Planomicrobium. Int J Syst Evol Microbiol 51, 1511-1520.

Zhang, D.-C., Wang, H.-X., Liu, H.-C., Dong, X.-Z. \& Zhou, P.-J. (2006). Flavobacterium glaciei sp. nov., a novel psychrophilic bacterium isolated from the China No.1 glacier. Int J Syst Evol Microbiol 56, 2921-2925.

Zhang, D.-C., Wang, H.-X., Cui, H.-L., Yang, Y., Liu, H.-C., Dong, X.-Z. \& Zhou, P.-J. (2007). Cryobacterium psychrotolerans sp. nov., a novel psychrotolerant bacterium isolated from the China No. 1 glacier. Int $J$ Syst Evol Microbiol 57, 866-869.

Zhang, D.-C., Liu, H.-C., Xin, Y.-H., Yu, Y., Zhou, P.-J. \& Zhou, Y.-G. (2008). Salinibacterium xinjiangense sp. nov., a psychrophilic bacterium isolated from the China No. 1 glacier. Int J Syst Evol Microbiol 58, 2739-2742.

Zhu, F., Wang, S. \& Zhou, P. (2003). Flavobacterium xinjiangense sp. nov. and Flavobacterium omnivorum sp. nov., novel psychrophiles from the China No. 1 glacier. Int J Syst Evol Microbiol 53, 853-857. 